\title{
Author's Journal as Type of Literary Edition
}

\author{
Olga Shilnikova, Olga Prokhvatilova, Alexander Mlechko, and Elena Ovechkina \\ Volgograd State University, Department of Journalism and media, 400062, Universitetskiy Avenue, 100, Volgograd, Russia
}

\begin{abstract}
Taking into account the structural features, peculiarities of the journal context and methods of its integration, the article demonstrates a typological model of the "author's" literary journal considered as one of the typological models of a large-volume journal (literary, universal, common journal type). The article reveals typological versions of the "author's" journals of Russian press in the $18-19^{\text {th }}$ centuries. The authors established that the general typological model united the "author's" journals with similar typological features. The owner, the publisher and the editor acted on his/her own, as well as he/she was the only or the main author of journal texts of different genres. Besides, he/she had an opportunity to create all journal discourses directly: artistic, publicistic, literary review which lead to the extreme consolidation of the journal context on the semantic (problem and thematic), formal (compositional and stylistic), worldview levels. The article proves that in the course of evolution, differentiation of the "the author's journal» model with the formation of its typological features has taken place. Russian journalism included the author's journal novel, the author's literary and artistic journal, the author's encyclopaedic journal, the author's monographic journal. The authors of the article demonstrate that typological versions of the author's journal are distinguished by degree of the publisher's and editor's involvement into the journal management process, their structure, ratio of the main journal discourses, volume and genres of the texts published, as well as methods of journal context consolidation.
\end{abstract}

\section{Introduction}

A large-volume journal (also known as literary, universal, common journal type) remains a priority for researches of a contemporary scientific discourse. Historians of journalism did a lot to identify the role of large-volume journals in the literary and social-political processes of Europe and Russia [1], [2-4]. The authors determined general typological features of the large-volume journal taking into account its historical genesis, structurally functional peculiarities, context specifics [5], poetics [6] and other aspects of style [7].

Meanwhile, a large-volume journal passed through several stages in its historical development. Journal content was not the only that underwent changes. A continuous transformation of the initial typological concept of editions, depending on the cultural, historical, political, economic conditions and the common state of the media, took place. As a result, a formation of various typological models inside the type took place.

However, the question about the variety of typological models of similar editions either is never asked as such, or is solved without true theoretical explanation and empirical verification.

In practice, the understanding of a productive historical experience of the journal context modeling can lead to the revival of modern literary journals. Cultural specialists, sociologists, historians of journalism and even journalists themselves have been declaring about protracted crisis they face for two decades. An experiment, the introduction of new journal forms in harmony with sociocultural requirements and technological realities of information epoch can help to overcome signs of a crisis. The process will be much more effective if we take into account journalistic traditions and innovative search of the past.

From the scientific point of view, reconstruction of the typology of one of the leading and known Russian printing editions of the $18-19^{\text {th }}$ centuries is necessary to present a fuller and more complete picture of the Russian journalism evolution in comparison with the Europewide media processes.

The object of the present article is to reveal and provide evidence of the previously undefined typological model of the large-volume author's journal and its typological versions, basing on the structural features and specifics of the context by means of typological, structural-functional and contextual analyses.

\section{Author's journal novel}

Literary and art journals, in which one person defined a general concept, a direction, contents of the edition as well as remained the only or the main author of the texts were a common practice for Russian periodicals of the $18-19^{\text {th }}$ centuries. 
They include satirical editions of the last third of the $18^{\text {th }}$ century, first of all "Adskaya Pochta" ("Infernal mail") by Fyodor Emin (1769) and "Pochta dukhov" ("Mail of spirits") by I.A. Krylov (1789), a typological nature of which researchers qualify as "journal novel" or "the journal in letters".

According to formal features, such a journal was more likely a collection of sketches or satirical letters feuilletons. Following its content, the edition was considered a complete art and publicistic text. The unity of the journal context was created through the close ideological and thematic concept of the parts, common preface and an image of the storyteller (however he/she was not a hero or a character) as well as the recurrent characters in the letters. The editor-publisher was the only author of the texts, which was reflected not only in worldview messages, but also in commonality of journal publications stylistics.

Thus, the journal novel (especially journal epistolary novel) was a unified and finished text. One of the main features of such editions was the syncretism caused by presence of the author who was a publisher and a storyteller in one person.

Generation of the author's journal novel typological model naturally took place during a period of prosperity of "personal" journalism. In Russia, that model was created under apparent influence of successful experience of the French literature, developing genres of philosophical and satirical letters, and the English press. The most typological similarity could be found in moral diaries edited by Richard Steel and Joseph Addison "The Tatler" (1709) and "The Spectator" (1711-1712) and also describing manners journals by Pierre de Marivo "Le Spectateur français" (1722-1723), "L'indigent philosophe" (1727) and "Le Cabinet du philosophe" (1734).

However, the fundamental cause of the syncretic journal forms combining signs of the art and publicistic work and printed media outlet predominance during that period, in our opinion, consisted in lack of large-volume author's journal formation as a type of the periodicals both in Europe, and later in the end of the 18 century in Russia.

\section{Author's literary and art journal}

"Moscow journal" is close to Krylov editions published in 1791-1792 according to some features. Its journal context was united by N.M. Karamzin's "literary identity", as the editor, the prose writer, the poet, the critic and the publicist. The concept and the program of the journal was composed by him personally immediately upon his return from the trip abroad in 1790 and included complete art, literary and critical modules. In the announcement "About the publication of "The Moscow journal" (Moscow Gazette1790. No. 89. November, $\left.6^{\text {th }}\right)$ the publisher insisted on his intentions to manage all the departments of the journal personally, to make up decisions about the selection of the authors and works for the publication, basing on his own preferences, as well as to fill the journal's literary part individually.
N.M. Karamzin managed to realize the plan to the fullest degree.

According to Yu.M. Lotman's fair remark, despite the other authors' cooperation, as well as the abundance of translated materials from various sources, the journal was considered a uniform lyrical "publisher's monologue" [8] with 9 out of 10 publications, created by the publisher himself. The editorials were noted with deep personal feelings and lyrical intonation, filled with almost intimate publisher's reference to "his dearest friends". Attitude towards the modern art and current events was directly expressed in criticism - both literary and theatrical. "Letters of the Russian traveler", close to autobiographical genre, and the lyrics with distinguishable biographic features were published from journal number to number [8]. A typological model of the first Karamzin's edition can be defined as the author's literary and art journal.

Due to numerous journal projects of N.M. Karamzin's followers, domestic romantics, editorial efforts of N.A. Polevoy, N.I. Nadezhdin and critical articles by V.G. Belinsky, the structure of the literary journal as a discrete, cross-genre and cross-personal periodical had been formed by the middle of the $30^{\text {th }}$ of the XIX century. Consequently, the audience did not accept the journal as a solid text or an independent literary work.

However, a peculiar version of the "author's" largevolume journal appeared during that period. It was presented by "Biblioteka dlya chteniya" ("Library for reading") edited by O.I. Senkovskiy (1834-1848) and had a number of significant features.

\section{Author's encyclopedic journal}

There is still no unified point of view about typological inhering of "Biblioteka dlya chteniya" ("Library for reading") by O.I. Senkovskiy. V.G. Belinsky, declaring about a variety of contents and forms of the context organization, notices that "Biblioteka" ("Library") has a full right to be the encyclopedic journal. Analyzing the editing principles, the critic emphasizes that the journal is ruled by "one person", and what is more the person is universally and comprehensively educated. T. Grits defines "Biblioteka" ("Library") as "the first large-volume encyclopedic journal" [9]. L. I Ginzburg notes that "Biblioteka dlya chteniya" ("Library for reading") was arranged as "a journal of one editor" [10]. L.V. Golubtsova proves that "Biblioteka" ("Library") should be referred to the type of journals "for a family reading" [11]. G.I. Scherbakova, basing on the priority of O.I. Senkovskiy's teaching function, determines the publication as a journal of "encyclopedic type", defining its typological model "a recurrence of personal journalism" of the $18^{\text {th }}$ century" [12].

Double meaning of the edition typological model identification is caused by a set of factors. Among them are a complexity of the journal architectonics, genre syncretism of the majority of publications, polydiscourse of the journal context, and uniqueness of the editor's personality, who is inclined to original stylistic and brave experiments with a journal form. 
Initially journal was created as a peculiar ideologically and esthetically neutral forum alien to the "spirit of the parties", journal disputes which did not protect a single "literary doctrine", that was openly demonstrated in the policy statement of the editor. However, a real journal discourse and the context formed by it were essentially other - rigidly unicentric under editor's intension, sharply polemical in relation to modern Russian journal literary space and at the same time dialogical focused on the establishment of close contacts with mass audience whose interest was a priority and constantly declared by O.I. Senkovskiy.

This difference of the approaches, however, caused constructive, substantial and morphological polyphony of the journal. The pointed refusal from disputes, which was publicly proclaimed and promised censorship commission, made O.I. Senkovskiy "create dozens of new journal forms which could be neither polemic, nor anti-criticism, but which remained his weapon till the very end" [13]. And finally, commitment to mass audience, but not to the elite reader made all journal materials adapt to audience apprehension, making them available, clear and interesting.

In fact, O.I. Senkovskiy was the owner, the editor and the publisher of the journal himself. A.F. Smirdin acted as the founder; however, his participation in editorial affairs was limited to material aspect. The announcement about new editions reported that O.I. Senkovskiy and N.I. Grecha's acted as the editors, however participation of the last was nominal as well.

The editor was an absolute master of the journal in organizational issues. Management of the journal had no traces of participatory beginning. "To avoid inappropriate guesses and rumors it is necessary to tell frankly that from the very beginning of this journal existence as it is almost known by everyone, its true editor has been the director himself and the owner of the journal, its editor, O.I. Senkovskiy. Nobody in the world except Senkovskiy had the slightest influence on the structure and contents of "Biblioteka dlya chteniya" ("Library for reading"), - O.I. Senkovskiy wrote in August 1836, addressing to readers [10].

There was no permanent editorial group and real employees in the journal either. Many contemporaries, including O.I. Senkovskiy's pupil P. Savelyev, indicated it. The first edition of the journal was bedecked with the list of 60 future journal authors' names. This list included all popular writers of that time, whose participation was seemed to be guaranteed (the editor did not come through, and he was sarcastically reproached by N.V. Gogol in the article "O dvizhenii zhurnalnoy literatury v 1834 i 1835 godu" ("About the development of Journal Literature in 1834 and 1835"). Of course, a certain circle of authors was published in the journal during different periods. However, it could change unexpectedly, and without any need but only due to the influence of editorial will.

O.I. Senkovskiy was, probably, one of the most active and exuberant authors of the journal. He wrote a lot of materials for the journal himself, and that was especially important, practically for all the departments and in all genres, including art. V.G. Belinsky who managed to evaluate O.I. Senkovskiy's creative versatility and efficiency nevertheless considered that such an active presence of one author in a journal resulted in monody of journal style, which, in his opinion, did harm to the edition.
Acting as a literary editor O.I. Senkovskiy was also an autocratic manager of "Biblioteka" ("Library"), which defined the general principles of the management. He was sure about his right to correct contents, to change the name of publications, to reduce and supplement them at his discretion. He spoke out of the quality of critical publications of "Biblioteka" ("Library") including his own and those by N.A. Polevoy (who cooperated with the journal after closing of "The Moscow telegraph" from 1836 till December, 1837) very negatively as the articles were mercilessly edited by O.I. Senkovskiy. Having decided to publish a separate book of his previous critical works in 1839 , N.A. Polevoy disclaimed almost everything he had written in 1836 and 1837 in the department of bibliography "It is not neither mine, nor the editor's, god knows whose that is, I'm the first who understands the least." [14].

O.I. Senkovskiy was also offhanded with original works of art. "It happened that Senkovskiy did not even read up manuscripts: he enjoyed the plot, and a happy idea came to his mind, he grabbed the end of the manuscript and attributed his own", - remembered P. Savelyev [15].

What is more O.I. Senkovskiy insisted on his right to make such corrections as means of significant improvement of the "quality" of the work: ("In Biblioteka dlya chteniya" ("Library for reading) edition in full sense, i.e. adding the accepted forms of the word and subject to the literary work, in case they require." (In Biblioteka dlya chteniya V. XVII, 7, Literaturnaya letopis. (1836)).

L.Ya. Ginzburg considered that O.I. Senkovskiy's editorial interference pursued several aims: "Sometimes he gave entertainment to an insignificant literary material; sometimes he realized his stylistic theories; sometimes he followed decent requirements; sometimes and finally he inserted something in another persons' works in polemic or self-promotion way" [10]. O.I. Senkovskiy, as we see, justified his arbitrary behavior by his desire to keep stability and consistency of the journal context.

However, this stability had reverse, i.e. unproductive side. "The true writer appreciates each letter and word, and too oppressive editor always has to surround himself with replications and insignificances or even stay alone, as it has happened with Senkovskiy" [16]. On A. Pushkin's, Zhukovsky's, D. Davydov's departure from the journal their places are taken by N. Kukolnik, A.V. Timofeev, L. Yakubovich, N.N. Verevkin, whose names are almost unknown to a modern reader.

The uniformity of the course was reflected in the text of the journal in various ways, including quite original ones and those aiming at both drawing the attention of the public and increasing a number of subscribers, as well as uniting a journal context.

A) By means of ideological unification of all the departments' materials due to monopolization of the only point of view, both editorial's and author's on the purpose of art, literature, offered the reader in literary and critical publications.

B) Due to the fictionalization and dramatization of the journal context in general, reached by means of mass use of game and role methods, for instance an ubiquitous Baron Brambeus image creation, development of original satirical genre forms, first of all literary and critical ones, as well as improvement of valuable literary and critical judgments 
representation ways. Literary mask and travesty genre were not O.I. Senkovskiy's invention. An application of fancy practices was rather traditional in Russian journalism and literary criticism. O.I. Senkovskiy's innovation and merit implied the essentially other, journal functions of a literary mask, having made "the mask" a constructive and integrating context element in general.

C) The certain stylistic and intonation unification which is based on those worldview and perception principles, focused in the images of baron Brambeus, functionally similar to it journal characters and the "literary identity" of the editor himself are well defined in journal context of "Biblioteka dlya chteniya" ("Literary for reading").

The worldview universum modelled by O.I. Senkovskiy, which joined the features of real O.I. Senkovskiy and his imaginary heroes, is analytical, basically rational, but not alien to adventurism, including intellectual one, also eccentric, knowing and understanding everything and thus trusting nothing and doubting everything relativistic "consciousness".

Such an intellectual matrix produced ironic and selfconfident, sometimes sarcastic and jokingly clownish, almost always familiar and idiomatic, seeking for destruction distances between subjects of speech and thus making them their companions, stylistic tonality of journal publications. Besides, the more O.I. Senkovskiy grew into a role of his character, the stronger that stylistic unification became. That point of view on the world was quite clear to readers the journal was assigned for, moreover, was well liked by them. Let us remind us that the audience, the editor was oriented to, was a provincial, but not a metropolitan public.

However, domestic journalism and its audience possessed also another experience, proving that the use of entertaining practices should not become the end in itself to the author. Creative tasks that can be solved with their help were essentially important.

The reputation of the journal, especially the author's one, was inevitably extended to the personality of the editor and vice versa. In addition, the reason is not in the life style, habits, personal qualities of O.I. Senkovskiy possessing huge encyclopedic knowledge and amazing working capacity, but in a traditionally Russian status of an editor, as a public person, a leader, presenting the public interests and ready to protect them.

Newspapers and journals of Russia of the second half of 1830-s were considered authoritative bodies, that formed public opinion and were able to influence the society. It was already impossible to abstract away from the certain social and political realities as well as from the fact that Russian literature was in breathless expectation and a presentiment of a new stage of the evolution development to both readers, and journalists.

Mainly due to it, the "author's" encyclopedic journal was unacceptable in Russia of the 40 -s of the $19^{\text {th }}$ century in the organizational and literary format, offered by O.I. Senkovskiy - with socially and esthetically indifferent criticism, with adjustment for exclusively playing methods of lecture communication, with unlimited editorial will. And from this point of view of O.I. Senkovskiy's journal, the experiment was doomed only for temporary success.

\section{Author's monographic journal}

During the further historical development, a typological model of the large-volume author's journal was present in Russian journalism. Several versions of the author's monographic journal appeared in the last third of the $19^{\text {th }}$ century. N.I. Dikushina typologically defined those editions as peculiar "individual" journals [17].

Thus, "Dnevnik pisatelya" ("Writer's diary") by F.M. Dostoyevsky was published in 1876-1877, 1880, 1881. L.P. Gromova called the edition a "monojournal" [18]. It included exclusively writer's publicistic articles, sketches, feuilletons, "anti-critic" publications, memoirs and art works of small uniforms.

"Dnevnik pisatelya" ("Writer's diary") by D.V. Averkiyev was published in 1885-1886. The journal was filled in with editor's fictional works, publicistic, theatrical criticism, memoirs, theoretical essays, as well as his own Heine's, Musset's, and Shakespeare's editorial translations.

F.M. Dostoyevsky's pupil A.V. Kruglov published "Dnevnik pisatelya" ("Writer's diary") in (1907-1909) as a "monthly public edition with illustrations" consisting of a mix of extracts from the press, letters from different places, answers to readers' questions.

Then the continuance of the same edition under the name "Svetoch and Dnevnik pisatelya" ("Great person and Writer's diary") as a "monthly illustrated literary and scientific journal for everyone" was published in 19101914. Here mainly the publisher's novels with continuation, verses, literary critical articles, religious publicism were published.

The reason of this typological model stability of the $19^{\text {th }}$ century was caused by the journal format popularity, and probably due to the fact that many domestic writers and journalists were confined by the jointly published and gained the influence of the one "with a direction" journal.

\section{Conclusion}

The revealed typological versions of the author's journal differed in the degree of the publisher-editor's involvement into the journal management, its structure, the ratio of the main journal discourses, the volume and a genre range of the published texts, ways of the journal context unification.

The general typological model of the "author's" journal was united by similar typological parameters. The owner, the publisher, the editor acted as one person. The editor was the only or the main author of journal texts of different genres. He had an opportunity to form all journal discourses: art, publicism, literary and critical directly. Intentionally designed virtual worldview universum firstly offered the readers the editor's point of view. The extreme solidity of a journal context on semantic (problem and thematic), formal (composite and style), world outlook levels occurred as a result of it.

\section{References}


1. A. Cross, Journal of European studies 46, 3-4, 378379 (2016)

2. A. Vichkitova, Sociological review 15, 68-90 (2016)

3. L. Reichstetter, Humour and laughter in history: Transcultural perspectives 15, 79-102 (2014)

4. Yu.A. Golovin, Russian literary and art magazines as a form of realization of cultural politics (MGUKI, Moscow, 2010)

5. O.G. Shilnikova, Typological algorythm of full-scale journal in Russia of XIX-XX centuries Bulletin of VolGU. Series 8. Literature studies. Journalistics. V.7, 65-77 (2008)

6. V.B. Smirnov Poetics of literary and art magazine as an issue of complex study Russian filology in the context of modern integration processes : in 2 volumes V.2, 383389 (VolSU, Volgograd, 2007)

7. O.A. Prokhvatilova, Observing the language of modern media Journalistics in 2013: regions in Russiam mediaspace (MediaWorld; Journalistics department of Moscow State University, Moscow, 2014)

8. Yu.M. Lotman, The creation of Karamzin (Young Guards, Moscow, 1998)

9. T. Grits, Barona Brambeus's Journal V.11, 20-26 (1928)

10. L.Ya. Ginzburg, Library for reading in 1830ies O.I. Senkovskiy Reviews on history of Russian lournalistics and critics (XVIII - XIX centuries) V. 1, 324-341 (Leningrad University printing house, 1950)

11. L.V. Golubtsova, Library for reading as a type of edition ( $\mathrm{PhD}$ dissertation, Moscow, 1993)

12. G.I. Scherbakova, O.I. Senkovskiy's journal "Library for reading» of 1834-1856 and formation of mass journalistics in Russia (PhD dissertation, Saint-Petersburg, 2005)

13. V.A. Kaverin, Baron Brambeus: Ihistory of Osip Senkovskiy, journalist, editor of «Library for reading» (Science, Moscow, 1966)
14. N.A. Polevoy, Ks.A. Polevoy, Literature critics: articles and reviews 1825-1842 (Belles-letters, Leningrad, 1990)

15. P. Saveliyev, About life and works of O.I. Senkovskiy Senkovskiy O.I. Collected edition, V.1, 11-115 (Imperator's academy of sciencies typography, SaintPetersburg, 1858)

16. Ye.A. Soloviyev, O.I. Senkovskiy: His life and literature activity in relation of his contemporary journalistics: biographic review (S.N. Khudyakov's printing house, Saint-Petersburg, 1892)

17. N.I. Dikushina, Literary journals and newspapers Sovetskaya entsyklopediya, Moscow, 189-192 (1987)

18. L.P. Gromova, "Time» and "Epoch» of M.M. and F.M. Dostoyevskiy History of Russian journalistics of XVIII-XIX centuries. (Saint-Petersburg University printing house, Saint-Petersburg, 2003) 